\title{
低温における熱拡散率と熱伝導率の 同一七ッティング測定
}

藤代 博之, 内藤 智之, 池 部 學, 能登 宏七

岩手大学工学部材料物性工学科 盛岡市上田 4-3-5

(1993 年 4 月 12 日受理)

Low Temperature Thermal Diffusivity and Conductivity Measurements under an Identical Experimental Setup

Hiroyuki Fujishiro, Tomoyuki NAITo, Manabu IKEBE and Koshichi NoTo

Department of Materials Science and Technology, Faculty of Engineering, Iwate University, 4-3-5 Ueda, Morioka 020 (Received April 12, 1993)

\section{Synopsis :}

A thermal diffusivity measuring system employing a closed cycle helium refrigerator was developed, which also enabled the thermal conductivity measurement under an identical experimental setup. The diffusivity was measured by a discretional heating method and the conductivity was measured by a steady-state heat flow method. The errors and the accuracy in measurements were evaluated by measuring the diffusivities of an austenitic stainless steel standard sample (SRM 1460), a Pyrex glass (Corning \$7740) and a high purity copper between 12 to $200 \mathrm{~K}$. The diffusivity ranging from $10^{-3}$ to $2 \mathrm{~cm}^{2} / \mathrm{s}$ could be determined with an uncertainty of $3 \%$. The results agreed with the reported values within $10 \%$.

\section{1. はじめに}

近年, 酸化物超伝導体に代表される低温工学, 低温 物理学の発展に伴い, 低温領域における諸材料の熱的 物性值（熱伝導率 $\kappa$, 熱拡散率 $\alpha$, 比熱 $C$ など）は, 実用的見地からも重要な物理量である。例えば，超伝 導機器やクライオスタットを設計する場合には, 固体 の熱容量が低温になるほど極端に小さくなるために， 使用する材料を伝わる熱侵入が重要な問題となる。ま た, 最近では新しい機能を持った各種複合材料, 薄膜 状材料の熱的測定も基礎，応用の両面から重要とな り，測定技術の確立も必要となってきている1)。これ らの熱物性值は $\kappa=\rho \cdot C \cdot \alpha$ (ただし， $\rho$ は密度）とい う関係で結び付けられているので， $\rho$ が既知の場合， $\kappa$ と $\alpha$ を独立に測定できれば比熱 $C$ を算出することが 可能である。また，熱桩散率は $\alpha=v \ell / 3$ という関係 で, 熱キャリアの速度 $v$ と平均自由行程 $\ell$ に結び付け られるので, 熱キャリアがフォノンのみでありフォノ ンの速度（音速）vが温度に依らず一定である場合に
は， $\alpha$ を測定することによってフォノンの平均自由行 程 $\ell$ 直接測定することが可能になる。低温における 固体の熱伝導率測定は一般に定常熱流法で行われ2), 比熱の測定は断熱法 ${ }^{3)}$, 熱緩和法 ${ }^{4)}$, 交流法 ${ }^{5)}$ なとによ って行われており，これまで多くの研究が報告されて いる。固体の熱拡散率測定は, ほとんどが非定常熱流 法で行われ，レーザフラッシュ法に代表されるような パルス状加熱による方法6), ステップ状加熱による方 法7,8)，周期加熱による方法9'などが一般的である。こ れらの方法は, 熱拡散方程式を解くための境界条件 （例えば，理想的なパルス状，ステップ状の温度変化） を実験的にも実現する必要があり，また等方的で均一 な試料を準備する必要がある。 $\kappa$ と $\alpha$ の同時測定は, 異なった試料や異なった実験から生じる誤差を少なく し, 比熱 $C$ の計算精度を上げることができる利点を持 っており，低温における測定においても Photopyroelectric 法 $^{10)}$, 温度の減衰曲線から解析する方法 ${ }^{11,12)}$ など，いくつかの報告が行われている。 我々は，すでにヘリウム泠涷機を用いた熱伝導率の 
完全自動測定システムを開発し，オーステナイト系ス テンレス標準試料の熱伝導率を 10〜200 K の温度範囲 で， $2 \%$ の精度で測定できることを報告した ${ }^{13)}$ 。ま た, 種々の酸化物超伝導体の熱伝導率を測定し, 熱的散 乱機構の解析を行っている ${ }^{14,15)}$ 。本研究では, この測 定システムに改良を加え, 熱伝導率の測定と同時に熱 払散率の測定を可能にした。低温における熱物性測定 の場合に問題になる輻射損失を極力少なくするため, 光学空の必要なレーザ光などの熱源を用いずに，微小 な金属皮膜チップ抵抗を熱源に用いた。熱伝導率 $\kappa$ は 定常熱流法により求め, 熱拡散率 $\alpha$ は任意加熱法と呼 ばれるパルス状加熱による非定常熱流法によって測定 した。この方法は, 任意の形状, 大きさの熱パルスに 対して熱拡散率 $\alpha$ を求めることができるという利点を 持ち，測定精度を向上させることができる ${ }^{16,17) 。 ま ~}$ た, 試料の形状が薄板状である場合, 面内方向と厚さ 方向の雨方向の熱拉散率測定が可能であり, 異方的な 熱物性值を持つ酸化物超伝導体単結晶のような試料に 対して，多くの情報を得ることができる。

\section{2. 実験方法および解析}

\section{1 熱拡散率および熱伝導率の測定方法}

熱伝導率に関する標準物質は，米国国立標準技術研 究所 (National Institute of Standards and Technology : NIST) などにより，数種類の標準物質が確 立され供給されている。しかし熱拡散率に関しては, 公的な機関によって認定された標準物質は存在しな い18)。したがって, 本研究では $\alpha=1 \mathrm{~cm}^{2} / \mathrm{s}$ 以上の大き な熱拡散率を持つ物質として高純度銅 (99.9999\%: $6 \mathrm{~N}$ : 同和鉱業(株) 製：サイズ $1 \mathrm{~mm} \dot{\varphi}$ ，長さ $50 \mathrm{~mm}$ ) を, $\alpha=0.01 \sim 0.5 \mathrm{~cm}^{2} / \mathrm{s}$ 程度の熱抬散率を持つ物質 としてオーステナイト系ステンレス標準試料 (SRM 1460 : NIST 製：サイズ $6.4 \mathrm{~mm} \psi$ ，長さ $50 \mathrm{~mm}$ ) を， それ以下の小さな熱搪散率を持つ物質としてパイレッ クスガラス (Corning \#7740: Corning 社製 : サイズ $5 \mathrm{~mm} \times 1 \mathrm{~mm} \times 15 \mathrm{~mm}$ )を測定し, 测定システムの精度, 信頼性を評価した。高純度銅は, 精製した原料を線状 に鋳造後，熱処理により鋳造欠陥を取り除き測定を行 った。パイレックスガラスは, ダイヤモンドカッター で切り出した後,ミラー研磨し測定を行った。Fig.1 に測定装置の試料周辺部分の概略図を示す。試料の一 端をへリウム冷凍機の cold headにインジウム半田ま たは，GE 7031 ワニスを用いて熱的に接触させ，他 端に熱伝導率測定の場合は温度差用ヒータ, 熱抬散率

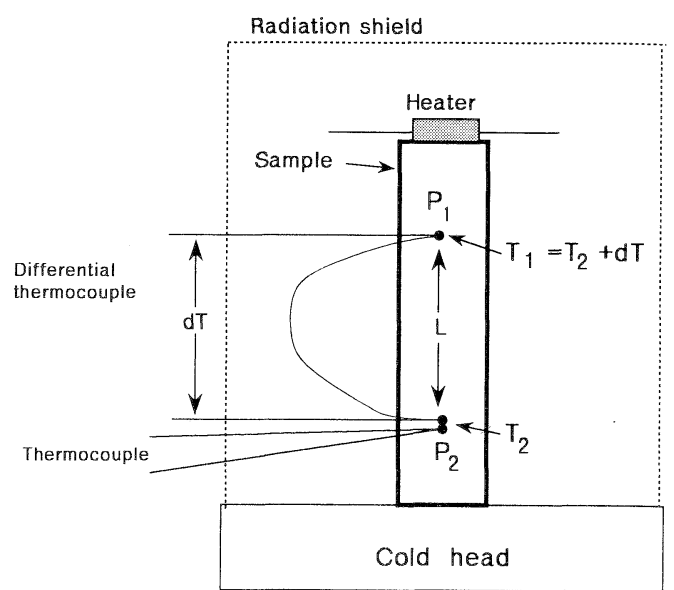

Fig. 1 Schematic diagram of the thermal diffusivity measurement system using a closed cycle helium refrigerator.

測定の場合は熱パルス用ヒータとなる金属皮膜チップ 抵抗 $10 \mathrm{k} \Omega$ (アルファ・エレクトロニクス(株)製：サ イズ $3.2 \mathrm{~mm} \times 2.5 \mathrm{~mm} \times 1.2 \mathrm{~mm}$ ) を GE 7031 ワニス を用いて接着した。cold head 側 (低温側) の $P_{2}$ 点 の温度 $T_{2}$ は, 直径 $73 \mu \mathrm{m}$ の $\mathrm{Au}+0.07$ at. $\% \mathrm{Fe}-$ クロメル熱電対を用いて測定し, 距離 $L$ だけ離れた ヒータ側 (高温側) の $P_{1}$ 点の温度 $T_{1}$ は, differential thermocouple ( $\mathrm{Au}+0.07$ at. \% $\mathrm{Fe}-ク$ ロル $-\mathrm{Au}+$ 0.07 at. $\% \mathrm{Fe}$ 差動熱電対）を用いて測定した $P_{1}, P_{2}$ の間の温度差 $d T$ を用いて $T_{1}=T_{2}+d T$ より求めた。 輻射による熱流入，熱損失を少なくするため, ニッケ ルメッキを施した銅製の輻射シールドを cold headに 熱的に接触させた。雾囲気気体による対流と熱伝導を 防ぐために, 試料室全体を油拡散ポンプを用いて $10^{-6}$ Torr 程度まで真空に引き測定を行った。測定装置は closed cycle type のヘリウム冷凍機, デジタルボル トメータ (DVM), 定電流源, パソコン等を GPIBケ ーブルで接続した自作の熱伝導率, 熱拡散率自動測定 システムを用い，12〜200 K の温度範囲で測定を行っ た。熱拡散率の測定は, 試料温度を安定させた後, 七 ータに 5 秒から 10 秒の電流パルスを加え, その後の $T_{1}, T_{2}$ の時間変化を毎秒 3.1 回，100（または 200） 秒間記録するという非定常熱流法により行った。用い た直径の熱電対の応答時間は $1 \mathrm{~ms}$ 程度という報告が あり ${ }^{19)}$, 十分正確に試料の温度変化を測定していると 考えられる。この結果を, 2.2 節で述べる熱㧪散方程 式の数值解析の結果と比較することにより熱拡散率 $\alpha$ 


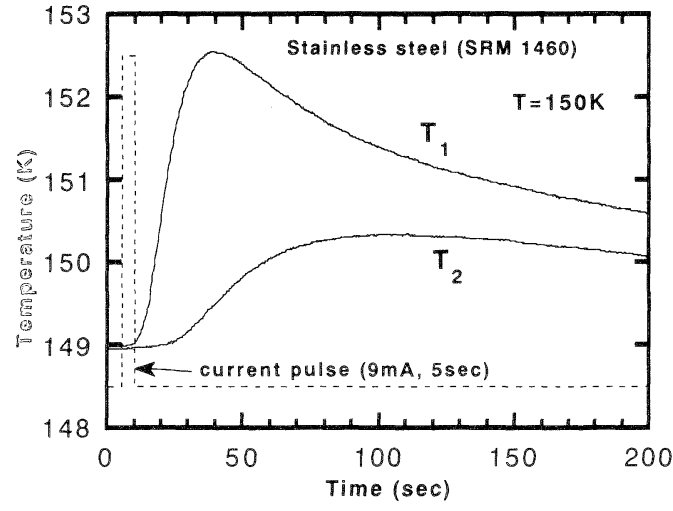

(a)

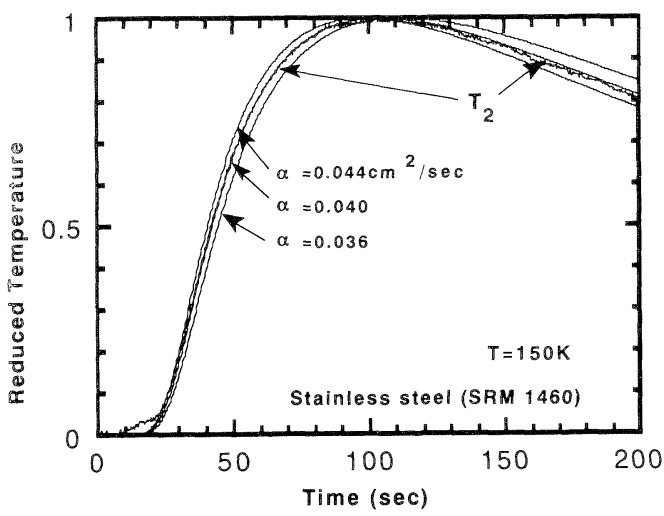

(b)

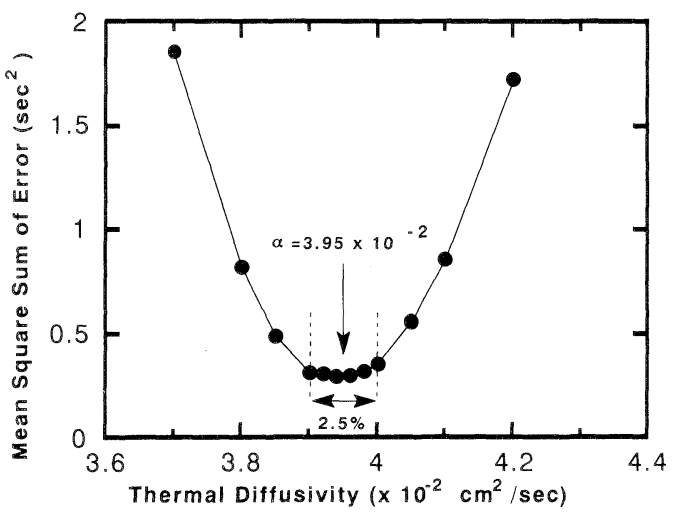

(c)

Fig. 2 The principle of determination of the thermal diffusivity $\alpha$. (a) the temperature changes $\left(T_{1}(t), T_{2}(t)\right)$ at the two measuring points $\left(P_{1}, P_{2}\right)$ for the stainless steel specimen (SRM $1460)$ at $150 \mathrm{~K}$, after applying the current pulse $(9 \mathrm{~mA}, 5 \mathrm{~s})$. (b) the comparison of the mea-
を求めた。熱伝導率の測定は，各測定温度で熱拡散率 を測定した後, ヒータに $P_{1}, P_{2}$ 間の温度差 $d T$ が約 $1 \mathrm{~K}$ となるように一定の電流を流し， $\kappa=Q / L(d T \cdot S)$

（ただし，Qは熱量， $S$ は試料の断面積）を用いて定 常熱流法によって求めた。

\section{2 熱拡散率の決定方法}

試料にヒータから熱パルスを加えた場合，輻射によ る損失がなく熱が cold head 側に一方向に流れると仮 定すると, 次の 1 次元の熱抬散方程式が成立する。

$$
d T / d t=\alpha\left(d^{2} T / d x^{2}\right)
$$

ここで, $T$ は温度, $t$ は時間， $x$ は距離， $\alpha$ は熱拡散 率である。ここで，時間軸を時間刻み幅 $\Delta t$ (刻み数 $i$ ), 距離軸を距離刻み幅 $\Delta x$ (刻み数 $j$ ) で分割し格 子点 $(u[i, j])$ を作る。この微分方程式を（2）式の ようにクランク・ニコルソン法 ${ }^{20)}$ を用いて陰的な差分 をとり近似差分方程式を作る。

$$
\begin{aligned}
& (1+C) u[i, j+1]-(C / 2)(u[i-1, j+1] \\
& \quad+u[i+1, j+1])=(1-C) u[i, j] \\
& +(C / 2)(u[i-1, j]+u[i+1, j])
\end{aligned}
$$

これに境界条件を代入すると，（1）の微分方程式は $n$ 元の線形代数方程式に書き換えることができる。この 連立方程式をガウスの消去法を用いて解くことで任意 の時間 $t$, 任意の距離 $x$ における温度 $T(t, x)$ を種 種の熱拡散率 $\alpha$ に対して計算することができる。本研 究では, 時閒刻み幅 $\Delta t$ を 0.32 秒, 距離刻み幅 $\Delta x$ を $0.5 \mathrm{~mm}$ で分割し，一連の計算を FORTRAN 言語で プログラムし，パソコンで計算を行った。実験におい ては, ヒータに電流をパルス状に流しているが，ヒー 夕部分の温度はヒータが有限の熱容量を持っているた めに理想的なパルス状の温度変化をせずに，時間遅れ を生じて変化する。そのため, 境界条件として理想的

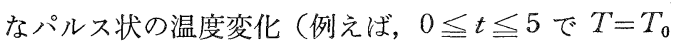
(一定)）を代入することはできない。そこで，実験 で求められた $P_{1}$ 点の温度変化 $T_{1}(t)$ を熱拡散方程 式の境界条件として代入し, 距離 $L$ だけ離れた $P_{2}$ 点

sured temperature change $T_{2}(t)$ with the calculated curves, $T_{2}^{\prime}(t)$, for various thermal diffusivity $\alpha$ : the measured change $T_{1}(t)$ was used as the boundary condition. (c) the mean square sum of the time differences, $\left\langle\left(t^{\prime}-t^{\prime \prime}\right)\right\rangle^{2}$ to fulfill the equivalent condition for the two curves, $T_{2}\left(t^{\prime}\right)=T_{2}^{\prime}\left(t^{\prime \prime}\right)$, against the parameter $\alpha$. Eighty points between the reduced temperatures 0.1 to 0.9 were used to evaluate the time difference, $\langle\Delta t\rangle^{2}$. 
の温度変化 $T_{2}^{\prime}(t)$ を任意の $\alpha$ に対して数值計算し て, 実験值 $T_{2}(t)$ と一致する $\alpha$ 值を最小自乗法に より決定した。この方法を用いれば，熱パルスの幅， 大きさが任意であっても試料中の距離 $L$ だけ離れた 2 点の過渡的な温度変化から熱拡散率を決定することが 可能となる。

Fig. 2 (a) に $150 \mathrm{~K}$ でステンレス標準試料に 5 秒間, $9 \mathrm{~mA}$ の電流パルスを印加した場合に測定された温度 変化， $T_{1}(t) ， T_{2}(t)$ を示す。また，Fig. $2(\mathrm{~b})$ に $T_{1}(t)$ を境界条件として (2) 式に代入し, 種々の $\alpha$ の值に対して計算した温度変化 $T_{2}{ }^{\prime}(t)$ と, 実際に 測定された温度変化 $T_{2}(t)$ とのフィッティングの様 子を最大温度変化を 1 亿規格化して示す。フィッティ ングを系統的に行らため, 立ち上がりの $10 \%$ から 90 $\%$ の間の 80 点の温度について計算值 $T_{2}{ }^{\prime}(t)$ と測定值 $T_{2}(t)$ の時間のずれ $\Delta t$ の平均自乗和を計算し, こ の和が最小になるように $\alpha$ を決定した。 $\Delta t$ の平均自乗 和と $\alpha$ の関係を Fig. $2(\mathrm{c})$ に示寸。この図から $150 \mathrm{~K}$ における $\alpha$ の最確值は $(3.95 \pm 0.05) \times 10^{-2} \mathrm{~cm}^{2} / \mathrm{s}$ と $\pm 1.25 \%$ の精度で決定することができた。

\section{3. 結果および考察}

\section{1 任意加熱法の検証実験}

本研究で用いている任意加熱法は, 文字ど拈り任意 形状の熱パルスに対して熱搪散率が求められるという 利点を持っている ${ }^{16)}$ 。本研究で用いた測定システムで このことを確認するために, 入力電流パルスのパルス 幅や大きさと, 求められる熱挔散率の関係について検 討した。Fig. 3 にステンレス標準試料についてヒータ 電流值を一定とし電流パルス幅を変化させた場 合の $150 \mathrm{~K}, 45 \mathrm{~K}, 12 \mathrm{~K}$ での熱拡散率の值を示す。電流パ ルス幅が極端に短い場合（2 秒以下）には温度変化が DVM の測定限界に近づくため測定精度が悪くなる が， 4 秒から 12 秒まで電流パルス幅を変化させても， 熱抬散率はばらつき $2 \%$ 以内でほぼ一定の值となるこ とがわかった。Fig. 4 に同じ試料について電流パルス 幅を 10 秒（一定）とし，電流パルスの大きさを変化 させた場合の $150 \mathrm{~K}, 45 \mathrm{~K}, 12 \mathrm{~K}$ に抒ける熱拡散率の 值を示す。電流パルスの大きさを変化させても，熱拡 散率はばらつき $3 \%$ 以内でほぼ一定の值となることが わかった。同様の確認実験は, 熱拡散率の絶対値が異 なる高純度銅とパイレックスガラスに対しても行い， 同程度のばらつきで熱拡散率が決定できることを確認 した。以上のことより，この熱拡散率測定法は任意形

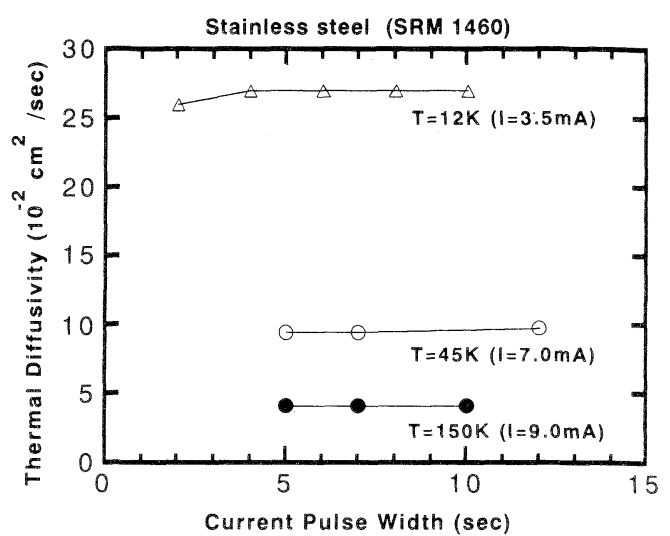

Fig. 3 Dependence of the determined thermal diffusivity on the current pulse width applied to the heater.

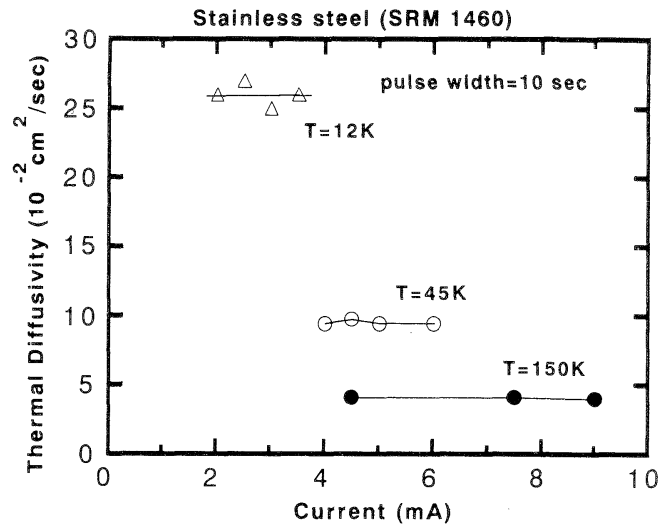

Fig. 4 Dependence of the determined thermal diffusivity on the current pulse height applied to the heater when the current pulse windth is fixed at $10 \mathrm{~s}$.

状の熱パルスに対してばらつき $3 \%$ 以内で熱拡散率を 決定できることが明らかになった。DVM の分解能や 輻射損失の影響を考慮して, 入力電流パルスの幅と大 きさは, $T_{1}(t)$ の変化が $3 \sim 5 \mathrm{~K}$ となるように各測 定温度で設定した。

\section{2 ステンレス標準試料（SRM 1460）の測定結果}

Fig. 5 (a) にステンレス標準試料の熱伝導率 $\kappa$ を, Fig. 5 (b) に熱払散率 $\alpha$ の温度依存性の測定結 果を示 す。Fig. 5 (a) 中には, 熱伝導率の NIST による較正デ ータ ${ }^{21)}$ を実線で示した。測定された熱伝導率は NIST の較正データと比較して $150 \mathrm{~K}$ 以下で約 $2 \%, 150 \mathrm{~K}$ 以上で約 4\%以内で精度よく測定された。Fig. $5(\mathrm{~b})$ に は, NIST により計算されたステンレス標準試料の熱 


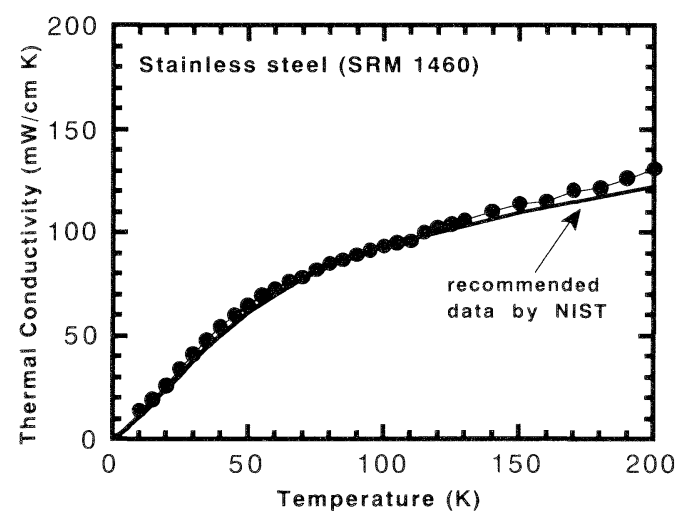

(a)

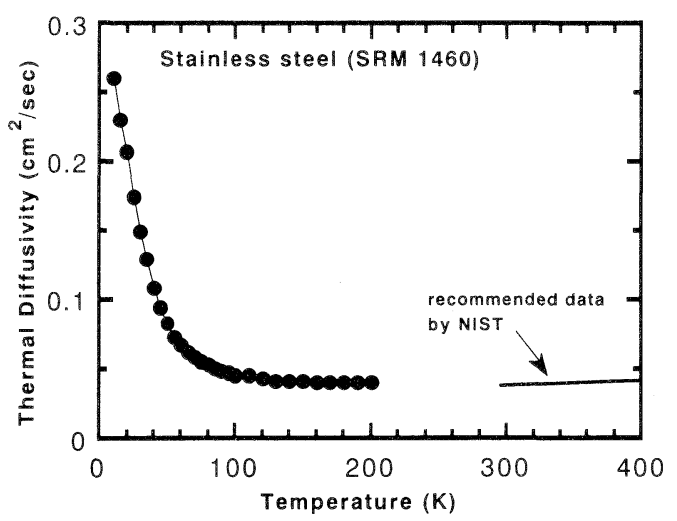

(b)

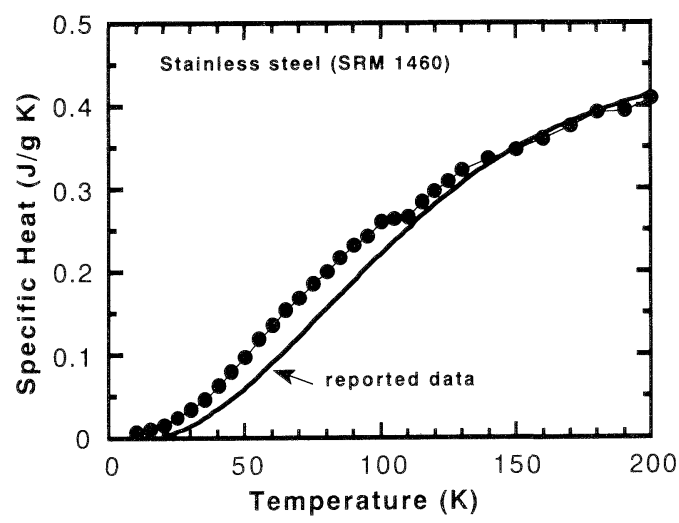

(c)

Fig. 5 The results of simultaneous measurement of (a) the thermal conductivity $\kappa$ and (b) the thermal diffusivity $\alpha$ for the austenitic stainless steel standard sample (SRM 1460), respectively. (c) shows the calculated specific heat using $\kappa, \alpha$ and $\rho$.

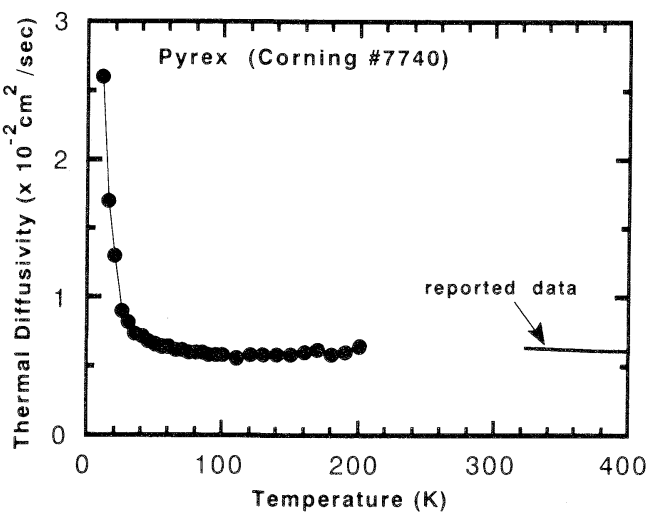

Fig. 6 Temperature dependence of the thermal diffusivity of the Pyrex glass (Corning $\$ 7740$ ). The thick line in the figure represents the data reported by Hulstrom, et al. ${ }^{24)}$

拡散率 ${ }^{22)}$ を実線で示した。NIST のデータを低温側に 外装した結果, 実験值と $200 \mathrm{~K}$ で約 $10 \%$ の違いで一 致した。測定された $200 \mathrm{~K}$ 以下でのステンレス標準 試料の熱拡散率は $100 \mathrm{~K}$ 付近まではほぼ一定である が，その後急激に増大して $12 \mathrm{~K}$ では $\alpha=0.26 \mathrm{~cm}^{2} / \mathrm{s}$ であった。Fig. $5(\mathrm{c})$ に, $\kappa, \alpha, \rho\left(=8.00 \mathrm{~g} / \mathrm{cm}^{3}\right)$ から 計算されたステンレス標準試料の比熱の温度低存性を 示す。文献 ${ }^{23)}$ のステンレス鋼が今回測定したステンレ 標準試料 (SRM 1460) と同一であるかどうかは不 明であるが，文献值と比較して $120 \mathrm{~K}$ 以上で $3 \%$,

$120 \mathrm{~K}$ 以下で約 $15 \%$ 以内で一致した。

\section{3・パイレックスガラスの測定結果}

Fig. 6 にパイレックスガラスの熱拡散率 $\alpha$ の温度 依存性を示す。図中には、レーザフラッシュ法で Hulstrom らにより測定された室温以上の熱拡散率の 值 ${ }^{24)}$ を実線で示した。200K 以下のパイレックスガラ スの熱拡散率の報告例は現在のところ見つからず直接 的な比較はできないが, Hulstrom らのデータを低温 側化外した結果, 測定值は $200 \mathrm{~K}$ で約 $2 \%$ 以内の 誤差で一致した。測定された $200 \mathrm{~K}$ 以下での熱拗散 率は， $50 \mathrm{~K}$ 付近まではほぼ一定であるが，その後急 激に増大して $12 \mathrm{~K}$ では $\alpha=0.026 \mathrm{~cm}^{2} / \mathrm{s}$ であった。

\section{4 高純度銅の測定結果}

高純度銅の熱抎散率は, ステンレス鋼やパイレック スガラスに比べ $2 \sim 3$ 桁大きく, かっ $100 \mathrm{~K}$ 以下の低 温では指数関数的に大きくなると報告されている ${ }^{25)}$ 。 そのため, 高純度銅の測定では大きな熱拡散率の測定 も可能になるように, 温度計距離 $L$ を長くして (38

Vol. 28 No. 9 (1993) 


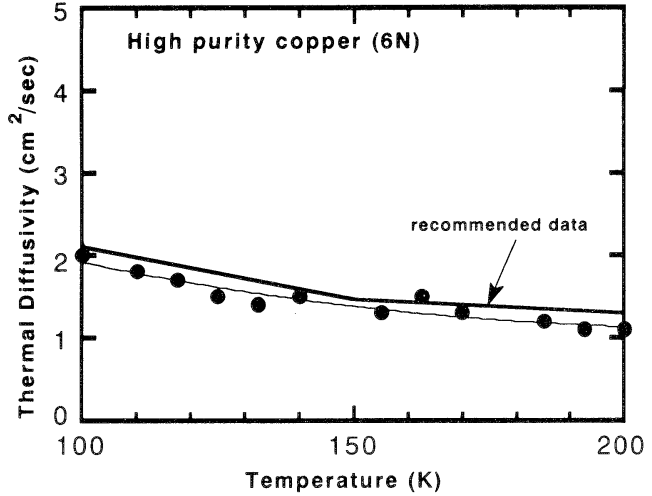

Fig. 7 The temperature dependence of the thermal diffusivity of the high purity copper $(6 \mathrm{~N})$. The thick line represents the recommended data by Touloukian, et al. ${ }^{25)}$

$\mathrm{mm}$ ) 測定を行ったが, 測定器のサンプリング速度 やGPIBによるデータ転送速度で決定される毎秒 3.1 回のサンプリング速度では $100 \mathrm{~K}$ 以下の大きな熱抎散 率は決定できなかった。Fig. 7 に高純度銅の熱拡散率 $\alpha$ の $100 \sim 200 \mathrm{~K}$ の温度依存性を示す。図中には，高 純度銅に対して推奨されている熱拡散率の文献值 ${ }^{25)}$ 太い実線で示す。測定された熱拡散率は文献值と比較 して，この温度範囲で最大誤差 $7 \%$ 以内で一致した。 高速 AD 変換などの手法を用いれば，さらに大きな 熱拡散率の測定も精度よく行うことが可能になると思 われる。

\section{4. まとめ}

ヘリウム冷凍機を用いて, 固体の熱拡散率 $\alpha$ を熱伝 導率 $\kappa$ と同一七ッティングで測定するシステムを開 発し，オーステナイト系ステンレス標準試料 (SRM 1460)，パイレックスガラス(Corning \$7740)，高純度 銅 $(99.9999 \%: 6 \mathrm{~N})$ を $12 \sim 200 \mathrm{~K}$ の温度範囲で測 定した。1 $10^{-3} \sim 2 \mathrm{~cm}^{2} / \mathrm{s}$ の範囲にある試料の熱拡散率 $\alpha$ をばらつきが $3 \%$ 以内で，また他の報告例と比較し た誤差が $10 \%$ 以内で測定できることがわかった。熱 電対の接点は有限の大きさを持ち, その接点をワニス を用いて試料に接着しているので，Lの測定精度が熱 伝導率, 熱拡散率の絶対精度に影響を及ぼすと考えら れる。本研究の場合の $L$ 測定には，ステンレス標準 試料，高純度銅の場合は最大約 $3 \%$ ，パイレックスガ ラスの場合は約 $8 \%$ の誤差を含むと考えられる。Lの 測定精度の向上とデータサンプリングの高速化により
さらに大きな $\alpha$ の測定や，さらに絶対精度がよい $\alpha$ ， $\kappa の$ 測定が可能になり, 酸化物超伝導体の散乱機構の 解明や各種低温材料の熱物性值の評価に役立つものと 考えられる。

本研究を進めるにあたり有益なご助言をいただきま した, 岩手大学工学部, 松川倫明助教授に感謝いたし ます。また，熱拡散率の報告例を提供してくださった 計量研究所, 計測システム部, 計測情報研究室, 新井 照男氏に感謝いたします。

\section{参考 文 献}

1) H. Shibata, H. Ohta and Y. Waseda : Materi als Transactions, JIM 32 (1991) 837

2) R. Berman : Proc. Roy. Soc. A 208 (1951) 90

3) H. Suga and S. Seki : Bull. Chem. Soc. Jpn. 38. (1965) 1000

4) R. Bachmann, F. J. Di Salvo, T. H. Geballe, R. Green, R. E. Howard, C.N.King, H.C.Kirsch, K. N. Lee, R. E. Schwall, H. U. Thomas and R. B. Zubeck : Rev. Sci. Instrum. 43 (1972) 205

5) P.F. Sullivan and G. Seidel : Phys. Rev. 173 (1968) 679

6) W. T. Parker, et al. : J. Appl. Phys. 32(1961) 1679

7）小林清志, 熊田俊明 : 日本原子力学会誌 9 (1967) 58

8) 熊田俊明, 小林清志：日本原子力学会誌 11 (1969) 462

9) 山田利之ら：第 6 回熱物性シンポジウム論文集 (1985) 229

10) S. B. Peralta, Z.H. Chen and A. Mandelis : Appl. Phys. A 52 (1991) 289

11) R.S. Knok, et al. : Rev. Sci. Instrum. 61 (1990) 809

12) A. Khalil : Cryogenics 22 (1982) 310

13）保原夏朗，松川倫明，松浦伸悌，藤代博之，能 登宏七：低温工学（印刷中）

14) K. Noto, M. Matsukawa, K. Mori, Y. Ogiso and K. Sato : Cryogenics 30 (1990) 868

15) M.Matsukawa, K.Noto, M.Ikebe and K.Mori: Proc. 7th US-Workshop on High Field Superconducting Materials, Wire and Conductors and Standardizing Procedures for HTSC Wires Testing (1991) 159

16）飯田嘉宏，重田治彦：日本機械学会論 文誌 47 (1981) 470

17）斎藤涁夫ら：日本機械学会論 文誌 52 (1986) 144

低温工学 
18）日本熱物性学会編：熱物性ハンドブック，養賢 堂, 584

19) C. D. Henning and R. Perker : J. Heat Transfer Trans. ASME 39 (1967) 146

20) J.Crank: The Mathematics of Diffusion, 2nd Edition, Clarendon Press, London (1975) 144

21) J.G. Hust and A. B. Lankford : NBS Special Publication (1984) 260

22) H. Groot: Proceedings of the 20th International Conference on Thermal Conductivity,
Plenum Press, New York (1989) 357

23）低温工学協会編：低温工学ハンドブック, 内田 老鶴圑新社, 192

24) L. C. Hulstrom, R.P. Tye and S. E. Smith : Proceedings of the 19th International Conference on Thermal Conductivity, Plenum Press, New York (1988) 199

25) Y.S. Touloukian, et al. : Thermal Properties of Matter, Vol. 1, 4, 7, IFI/Plenum Press, New York (1970) 